\title{
Weed management in no-till winter wheat (Triticum aestivum L.)
}

José M.G. Calado ${ }^{\mathrm{a}, \mathrm{b}, *}$, Gottlieb Basch ${ }^{\mathrm{a}, \mathrm{b}}$, Mário de Carvalho ${ }^{\mathrm{a}, \mathrm{b}}$

a University of Évora, Crop Science Department, Apartado 94, 7002-554 Évora, Portugal

${ }^{\mathrm{b}}$ Institute of Mediterranean Agricultural Sciences (ICAM), Apartado 94, 7002554 Évora, Portugal

Article history:

Received 23 March 2009

Received in revised form 22 September 2009

Accepted 27 September 2009

\section{a b s t r a c t}

In general, effective weed control in no-tillage systems is based on the use of herbicides. However, the development of appropriate weed management strategies can help to reduce the amount of herbicides applied.

In this study weed management in common wheat under no-till was analyzed. The experiment was carried out under Mediterranean conditions on a Luvisol, during two growing seasons (1996/1997 and 1999/2000). A split-plot design with four replications was used. The main plot was weed emergence before wheat sowing (with and without weed emergence) and the subplot was the postemergence weed control (with and without post-emergence herbicide).

The density of the weeds was significantly reduced when the wheat crop was sown after a considerable part of the weeds had emerged and controlled by a presowing herbicide (non-selective, systemic and non-persistent). Without weed control in post-emergence treated plots, the number of grains and the yield was increased significantly, compared to sowing without weed emergence. It can be concluded that under Mediterranean conditions, it is possible to reduce or even avoid the application of post-emergence herbicides in wheat under no-till, as weeds can be efficiently controlled before sowing.

Keywords: No-till Wheat Weed density Weed control Weed emergence

* Corresponding author. University of Évora, Crop Science Department, Apartado 94, 7002-554 Èvora, Portugal. Tel.: +351 266 760822; fax: +351 266760828. E-mail address: jcalado@uevora.pt (J.M.G. Calado).

0261-2194/\$ - see front matter 2009 Elsevier Ltd. All rights reserved. doi:10.1016/j.cropro.2009.09.011 